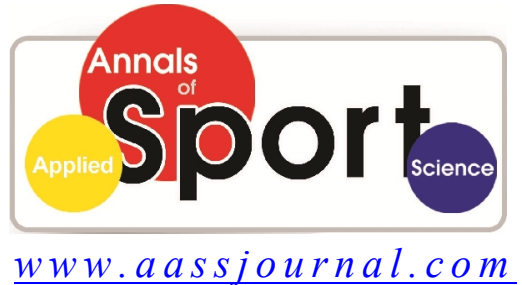

ISSN (Online): 2322 - 4479

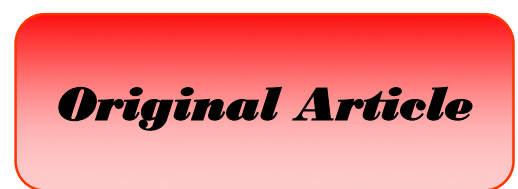

Received: $19 / 02 / 2014$

Accepted: 05/04/2014

\title{
Fan Based Brand Equity (FBBE) Factor Analysis of Football in Iranian Premier League Clubs
}

\section{${ }^{1}$ Mohammad Rasoul Khodadadi*, ${ }^{1}$ Abolfazl Farahani, ${ }^{2}$ Hamid Ghasemi, ${ }^{3}$ Habib Honari}

1. Department of Physical Education and Sports Sciences, Tehran Branch, Payam Noor University, Tehran, Iran.

2. Department of Physical Education and Sports Sciences, Karaj Branch, Payam Noor University, Karaj, Iran.

3. Faculty of Physical Education and Sports Sciences, Allameh Tabataba'i University, Tehran, Iran.

\begin{abstract}
This research aims to validate and factor-analyze the Fan Based Brand Equity (FBBE) questionnaire of football in Iranian supreme league clubs. The present research is of descriptiveanalysis type and has been done by survey method. The statistic population included football clubs fans of the Iran's 13th supreme football league, and the sample society was 880 people chosen from seven clubs fans present at stadiums by using Cochrane's formula based on available samples using random category and clustering methods. The research instrument was an author-made questionnaire. The whole content reliability of questionnaire was CVI=0.91 and its validity was calculated through two validity methods of test and retest (ICC) was 0.89 . The internal reliability was calculated greater than 0.8 for 52 items through Cronbach's Alpha. Software SPSS 20 was used to perform the exploratory and confirmatory factor analysis. According to the results of factor analysis of 52 items on FBBE questionnaire, 7 items were deleted in the exploratory analysis and 45 items were placed in 5 factors. Finally, FBBE questionnaire has been confirmed with 12 items brand association attribution, 7 items for brand association benefits, 6 items for brand association attitude, 12 items for brand identity, 6 items for tangible identity, 6 items for intangible identity, 8 items for brand loyalty, 4 items for behavioral loyalty, and 4 items for attitudinal loyalty in confirmatory factor analysis.
\end{abstract}

Key Words: Brand Association, Brand Identity, Brand Loyalty, Fans, Football.

Corresponding Author:

Mohammad Rasoul Khodadadi

E-mail: rm_kh85@yahoo.com 


\section{INTRODUCTION}

Asia's nowadays sports market is described by globalization with media involvement, sponsorship, and the development of sport-related industry. International organizations tend to conquer new and assured markets especially in Asia as the third global society including some of the most rapidly developing opportunities in the world (1). In the knowledge-based competition age, organizations' ability to develop and gather invisible assets is considered an essential action to succeed in take part in the competitive market. Invisible assets create most of the organizational development and value for owners and shareholders and contribute to the half of companies' market value at least (2). Brand is one of the most important invisible assets which have lately been touched on. Using the customer-based brand equity, football clubs can learn how their rivals have become distinct in a foreign market and what factors influence the quality of their brand effectively. Clubs must clearly specify who they are (their identity), what purpose they want (decision making and targeting), how they want to be seen (understood), and how they distinguish themselves from their major competitors (their position) (3-5). Brand equity is an added value which has been added to the brand because of its name. Brand equity or goodwill of name means the right or value is resulted by successful performance of an organization (2). Each brand keeps an extent of value which is defined its asset within itself. Organizations bearing more brand equity will have an output (6). In a definition, Claire (1993) states, "Once the brand is known and its related factors or its associations become strong, desirable, and unique in customer's mind, brand equity is created" (7). Studying brand association in sports team fans in order to provide a base on which brand equity is built is important and essential. Creating brand association helps create brand loyalty and increase brand equity $(8,9)$. It is quite important for sports marketers to understand the types of associations which customers have while consuming the products of a sports team (10). In fact, the method of evaluating customer-based brand equity and measuring the brand equity is based on customers' reactions to the brand, a fact which is reached by the very knowledge, awareness, and familiarity (8). It is the customers who prefer one brand to another through their purchases based on factors they consider important and value a specific brand. As a result, Customer-Based Brand Equity or CBBE will be more efficient to get close to what is in customer's mind about a certain brand. However, the brand is supposed to be loyal to its own identification if it wants to be strong. Different dimensions have been considered for brand identity. These dimensions include apparel and graphic features of the brand, its character, its connection with audiences, culture, quality, and other factors (11). The attempt to copy makes managers forget the identity of their own brand and blend in the society. The brand loses its touch through opportunism and populism which make the brand change into an ornamented appearance representing nothing. The identity can represent the quality of the brand (12). Well-organized brands provide the market-oriented organizations with an approach, and researches' attention changed from concentrating on brand's image to creating an identity for brand after a while (3). Bauer, Stokburger-Sauer, and Exler (2008) and Ross, Russell, and Bang (2007) believe that 2000 s is a decade when managers' activities will change from concentrating on teams' success as a mean for achieving short-term benefit to concentrating on 
strategic management of team's or organization's brand as a mean for achieving long-term asset (13). Sports organizations do activities in a complicated and competitive environment at national and international level. Most of these organizations are trying to create loyalty among fans and their members and to attract sponsors support. Sports organizations should create a strong image in their customer's mind to achieve these goals. When a sports organization can create a strong image in customer's mind, it fulfills its brand equity. If the brand equity is high, it leads to brand loyalty, guaranteeing commercial sales and ticket sales (8). After that, sponsors are encouraged to cooperate with the brand. On the other hand, sports organizations are of those which provide services rather than wrapped goods (14). Ross (2006) states, "Concepts mentioned in the field of branding are mostly based on tangible and hand-made goods, whereas sports services are basically intangible and rapidly wearable" (15). Barry (2000) believes that sports services are intangible, are not packaged, and are not labeled, so the brand associates with the organization rather than with the product, therefore, organizations' fame and reputation affects the understanding of sports services customers (16). Because, to the consumer of sports services, the reputation of serviceproviding organization is considered to be an important sign of its quality (13). Of other characteristics of sports services is the fact that when the spectator is watching a team's play or a customer is using the sports services, they are directly observing the service delivery process, too. The experience which a customer gains during this process affects the mental image of the organization. Barry (2000) says that customer's experience is very important in developing brand equity (16). Other characteristics of these sports services include physical proximity, verbal interaction, and mouth-to-mouth communication with customers which are waiting for the services, like spectators in a stadium. This special condition affects the experiences of sports service customers, so it needs control and direction. Also, evaluating sports services is hard because of its intangibility, and the customer cannot have a good evaluation before purchasing (15), like watching a football match. With this explanation, paying attention to the name of a sports club or brand of these types of organizations bears greater importance. Elahi et al. (2009) believes that anonymity and little credibility of the brands of clubs and Iranian professional league is the obstacles for developing investment and sponsorship in country's football industry at national and international level (5). Javani et al. (2012) has inferred that all three factors of assets, benefits, and brand association approaches affect the extent of fans' loyalty, considering brand association benefits to be the most effective on the extent of loyalty (8). Boroumand et al. (2011) inferred that prestige, customer's satisfaction, and corporate communication are positively related to the identity of trademark. The identity of trademark is also positively related to repurchase and mouth-to-mouth recommendation or advertising by the customer (9). The findings of a research by Dehdashti, Jafarzadeh Kenari, and Bakhshizadeh (2012) indicated the positive effect of brand identity on brand loyalty and their direct relationship (17). A brand with strong identity is the origin of forming longterm relationships between customer and company, resulting in loyalty. In the research by Sajadi, Khabiri, and Alizadeh (2013), results indicated that three factors of brand association features including head coach, management, and badge had positive effect on loyalty. Factors like escape and fans identity are of brand association 
benefits bearing positive effects, and acceptance of peers had negative effects on loyalty, while two factors of importance and knowledge among factors of brand association approach had positive effects on fans loyalty to club's brand (18). Moshbaki et al. (2014) presented a new viewpoint on dimensions of brand equity of country's football, using factor analysis and the pattern of structural equations (19). In the order of factor weight, it included success (0.97), product delivery $(0.92)$, team's local are (0.89), star players (0.88), logo, fans, history record, traditional rival $(0.87)$, tradition (0.85), team's performance $(0.82)$, stadium (0.72), and personnel (0.51) (19). In the research by Gladden and Funk (2002), 13 dimensions were identified as potential dimensions of brand association in sport, and 7 dimensions of them were significant predictors of loyalty to the brand among fans of this study. Fans' feeling of identity was a strong predictor of loyalty to the brand (10). Lyn (2007) came to this conclusion that the concept of loyalty to brand can be described through dimensions of brand association (assets, benefits, and attitude). But this loyalty is not influenced by demographic characteristics of fans. Fans may support a team because of assets like stadium, head coach, star players, and the number of wins, and the benefits and attitude resulted by creating desirable moments in accompanying the team increases this support and causes fans loyalty to team brand even if the team loses (20). Ross, Russell, and Bang (2007) believe that there are 49 items and 13 structures of an appropriate, logical model in studying the development of understanding of the rights of shareholders through sports trademark in the eye of consumers presenting experimental support for the model (13). This study is an initial and experimental test for Spectator-Based Brand Equity (SBBE) as well as indicating the importance of discovering methods to understand spectator-based share right. Carlson and Donavan (2013) believe that customers usually feel an identity toward their team through team's sub-brand, spending money in retail stores, and watching the matches (21). In a study, Koo (2009) inferred that fans who deeply feel an identity toward their team are highly likely to keep and maintain loyalty to that team (22). Cui (2011) concluded that four dimensions of brand equity had considerable effects on brand equity (23). The brand image had a positive effect on the dimensions of brand equity. Biscaia et al. (2013) stated the valid tools to measure brand equity in professional teams in ten dimensions including trademark, score, social interaction, commitment, team's history, organizational characteristics, team's success, head coach, management and staff, and stadium (24). We can see that researches conducted in the society evaluated spectators' brand equity but did not pay attention to the real football customer i.e. fans who are the most persistent customer of sports services. However, the main quintessence of brand meaning brand identity has not been studied along with brand associations and been kept in a big obscurity except for in the research conducted by Gladden and Funk (2002) which was a main and basic research on this matter (10). Therefore, it is essential that fan based brand equity of football be carefully analyzed along with brand identity and its appropriate tool be presented in order for the evaluation in Iranian football supreme league. Finally, this question rises, "What variables affect fan based brand equity in order to achieve loyalty?"

\section{MATERIALS AND METHODS}

The present research has been of descriptive-analytic and done in the survey mode. 
Participants. The statistical society included fans of football clubs present in Iranian 13th football supreme league, and the statistical sample consisted of 880 people (using Cochrane's formula and enough number of samples in the factor analysis) and seven clubs (Esteghlal, Persepolis, Teractor Sazi, Sepahan, Foolade-Khoozestan, Malavan, and Mess) of the society which have been chosen through stratified and clustered random sampling.

Instruments. Funk's and Gladden's model (2001) was used to design the research tool, and Javani's questionnaire (2012) was used in brand associations (8), while Kapferer's model (2008) was used in brand identity (25), and Møller Jensen and Hansen model of behavioral and attitude questionnaire (2006) were the base of FBBE questionnaire (26). Considering the fact that this questionnaire has been designed to be used in fans society, it finally was designed with 54 items for mentors and other specialists in a way that the items were clear and coherent. The research questionnaire was provided in the form of Likert's sevenstep scale in order for greater precision in evaluating fans' viewpoint and due to a wide range of subject matters and many subscales and variables (totally disagree: 1 to totally agree: 7). This leads to the fact that factor analysis will become possible to discover the relationship between mass variables in Likert's scale.

Protocol and Statistical Analysis. Two types of validity have been evaluated to understand the validity of this questionnaire: content validity and construct validity (factor analysis). Lawshe's model (1975) was used to determine the content validity (27), and a questionnaire aligned with research's goals and theories was designed in Likert's four-degree from irrelevant to highly relevant with band scores from 1 to 4 and was given to 10 specialists of management, sports economic, and marketing. These people were asked to state their opinions on the relationships of items with variables, an item which should be added or omitted, misspellings, grammatical errors, and literal ones. To quantify the votes by the members of specialists group, the number of votes for each item was separately added up and divided by the total number of specialist group, and the result for each item was the content validity of that item. To acquire the whole content validity of questionnaire, the whole validity of items were added up and the result was divided by the total number of items. Eventually, Content Validity Index was acquired CVI= 0.91 .

Two methods of test-retest reliability and internal reliability were used to evaluate the reliability of questionnaire. Interclass Correlation Coefficient (ICC) in the software SPSS was used to calculate testretest reliability. The questionnaire was collected from 50 members of the statistical society in two different stages with a 10-day interval. The mean of data was calculated, and the correlation of means was calculated as 0.89 through ICC test. The coefficient of Cronbach's Alpha was acquired greater than 0.8 for 52 items out of 54 ones and lower than 0.8 for the other two items which eventually were deleted for the questionnaire to bear a very good reliability. Therefore, the final number of items declined to 52, and it was considered as the final questionnaire to be distributed among subjects. Also, the coefficient of Cronbach's Alpha was calculated for each item in a way that the coefficient and the whole reliability would increase if the item was deleted; it was acquired greater than 0.8 for all items. Cronbach's test was also used to evaluate the negative and positive weight of the items. Items with the most negative weight can be identified and deleted in this method. Because deleting the items with negative results in increasing the internal reliability 
of the questionnaire as possible. 52 out of 54 items remained in this questionnaire due to the least negative weight. Eventually, Cronbach's Alpha test was used to examine correlation coefficient of each item with the whole questionnaire. According to studies by Streiner and Norman (2008), the correlation coefficient of each item with the whole questionnaire must be over 0.2 so that item reliability can be trusted (28). In this questionnaire, the correlation coefficient of every item is greater than 0.2 , therefore, every item of this questionnaire bears a good reliability. The research data were considered in descriptive view to determine mean, standard deviation, frequencies, percentages, and diagrams. The software SPSS 20 was used to conduct confirmatoryexploratory factor analysis.

\section{RESULTS}

Exploratory factor analysis. The purpose of evaluating the construct validity is to answer the question how much the structure of questionnaire is consistent with its goal. The correlation pattern between variables are measured and then categorized by using statistical methods. It is expected that questions categorization follow a logical pattern. The factor analysis method consists of four steps including elementary analysis, extracting factors, rotation, and interpretation, respectively. The initial analysis included correlation coefficient matrix, the magnitude of correlation coefficient, and its being positive or negative between the items and the significance level matrix from which items with greater negative weight and items whose correlation has not been acquired at a significance level of 0.05 have been omitted as many as seven ones. The determinant test was used to evaluate the whole correlation equal to 0.355 , and this means that data are neither completely correlated (one) nor separated from each other (zero). Then Kaiser-Meyer-Olkin (KMO) Measure of Sampling Adequacy was used to determine the adequacy of sample size which was acquired as 0.82 for the whole questionnaire. Bartlett's test of sphericity was used to evaluate correlation between items. The result must be significant for items so that their correlation can be understood. The result of Bartlett's test has been acquired significant for most of items in this research $(\mathrm{p}=0.001)$ (Table 1$)$.

Table 1 - The results of KMO and Bartlett's Test

\begin{tabular}{lccc}
\hline Kaiser-Meyer-Olkin Measure of Sampling Adequacy. & $\mathbf{0 . 8 2}$ \\
\hline \multirow{3}{*}{ Bartlett's Test of Sphericity } & Approx. Chi-Square & 23310.995 \\
\cline { 2 - 3 } & df & 859 \\
\cline { 2 - 3 } & p & 0.001
\end{tabular}

Given the index of $\mathrm{KMO}$ equal to 0.86 and Bartlett's test equal to $\mathrm{P}=0.001$, the results indicate the appropriateness of construct validity. Principal Axis Factoring (PAF) method was used to extract the factors. This method showed us the Initial Eigen Values, one of which was greater than one, and we can have as many factors as them in our questionnaire. In this questionnaire, the Initial Eigen Value greater than 1 happened 5 times which showed the items extracted from this questionnaire (Table 2). Also, the number of items has been specified in this questionnaire by using Screen Plot method, and it was 5 items (Figure 1). 
Table 2 - The result of extracting the items by using the Initial Eigen Value

\begin{tabular}{c|ccc}
\multirow{2}{*}{ Factors } & \multicolumn{3}{c}{ Extraction Sums of Squared Loadings } \\
\cline { 2 - 4 } & Total & Variance (\%) & Cumulative variance (\%) \\
\hline One & 16.163 & 35.918 & 35.918 \\
\hline Two & 4.684 & 10.408 & 46.327 \\
\hline Three & 2.912 & 6.471 & 52.798 \\
\hline Four & 1.943 & 4.317 & 57.115 \\
\hline Five & 1.692 & 3.760 & 60.875 \\
\hline
\end{tabular}

Table 3. The extent of correlation of each questionnaire item in factors

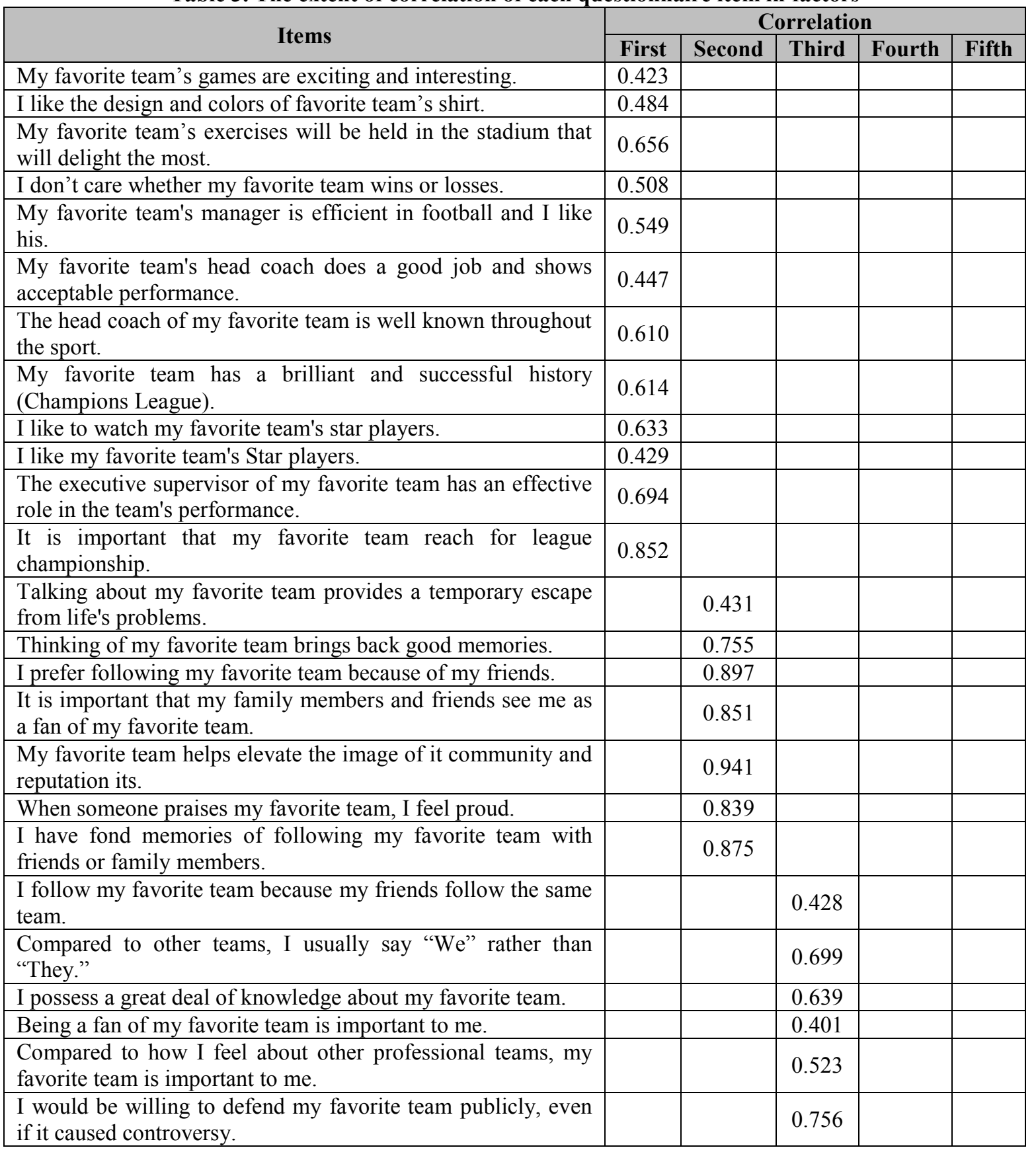


Continue Table 3

\begin{tabular}{|c|c|c|c|c|c|}
\hline \multirow{2}{*}{ Items } & \multicolumn{5}{|c|}{ Correlation } \\
\hline & First & Second & Third & Fourth & Fifth \\
\hline $\begin{array}{l}\text { My favorite team is famous and familiar among football } \\
\text { teams. }\end{array}$ & & & & 0.711 & \\
\hline $\begin{array}{l}\text { Wherever the name my favorite team is spoken, automatically } \\
\text { its logo reminded to me. }\end{array}$ & & & & 0.478 & \\
\hline My favorite team makes a good relationship between the fans. & & & & 0.693 & \\
\hline My favorite team causes a link to different people. & & & & 0.587 & \\
\hline The logo of my favorite team shows the features of my own. & & & & 0.425 & \\
\hline $\begin{array}{l}\text { My favorite team's logo is a reflection of my favorite team and } \\
\text { my fandom aims. }\end{array}$ & & & & 0.698 & \\
\hline $\begin{array}{l}\text { The logo of my favorite team has a strong and worthy } \\
\text { character. }\end{array}$ & & & & 0.489 & \\
\hline My favorite team's logo is exciting, valuable and complicated. & & & & 0.451 & \\
\hline My favorite team has an enriched culture and history. & & & & 0.871 & \\
\hline My favorite team associates good internal values. & & & & 0.414 & \\
\hline I have internal relationship with my favorite team's logo. & & & & 0.523 & \\
\hline My favorite team enhances my self-improvement. & & & & 0.412 & \\
\hline I consider myself as a committed fan of my favorite team. & & & & & 0.405 \\
\hline $\begin{array}{l}\text { I cannot ever cut my attachment from my favorite team to } \\
\text { another. }\end{array}$ & & & & & 0.514 \\
\hline $\begin{array}{l}\text { I will forgive my favorite teams defeat in the way of } \\
\text { achievement. }\end{array}$ & & & & & 0.849 \\
\hline Joining more fans to my favorite team makes me glad. & & & & & 0.824 \\
\hline $\begin{array}{l}\text { I try my friends and my family be included in my favorite } \\
\text { team fans. }\end{array}$ & & & & & 0.475 \\
\hline $\begin{array}{l}\text { I purchase some of my favorite team products in particular } \\
\text { times. }\end{array}$ & & & & & 0.477 \\
\hline $\begin{array}{l}\text { In particular time I will participate in the games of my favorite } \\
\text { team. }\end{array}$ & & & & & 0.523 \\
\hline $\begin{array}{l}\text { I follow my favorite team games without considering who the } \\
\text { opposite team is. }\end{array}$ & & & & & 0.474 \\
\hline
\end{tabular}

Rotation. The method of Oblique of Direct Oblimin type was used in this part of factor analysis. Extracting the factors was done by assuming the items to possess a factor weight of greater than 0.4. Also, since the number of factors extracted by Screen Plot was 5, while this number was 6 by Initial Eigen Value, the reliability of questionnaire was separately evaluated with 5 and 6 factors with relevant items. The result indicated that questionnaire reliability of 5 factors was greater than that of 6 factors, so the number of factors was decided to be 5. Finally, what came out of this research was to decrease 45 items to 5 factors which totally covered $60.87 \%$ of variance and indicated that the factor analysis and items had been satisfactory. Given the extent of correlation of each index, we can choose appropriate names or titles for each of them as the following ones. The Initial Eigen Value for the first factor is 16.16 which is able to calculate $35.91 \%$ of the variance, and 12 items have been loaded in it. The Initial Eigen Value for the second factor is 4.68 able to cover and explain $10.40 \%$ of variance. 7 items have been loaded in this factor. The Initial Eigen Value for the third factor is 2.91 able to cover and explain $6.47 \%$ of variance. 6 items 
have been loaded in this factor. The Initial Eigen Value for the fourth factor is 1.94 able to cover and explain $4.31 \%$ of variance. 12 items have been loaded in this factor. The Initial Eigen Value for the fifth factor is 1.69 able to cover and explain $3.76 \%$ of variance. 8items have been loaded in this factor.

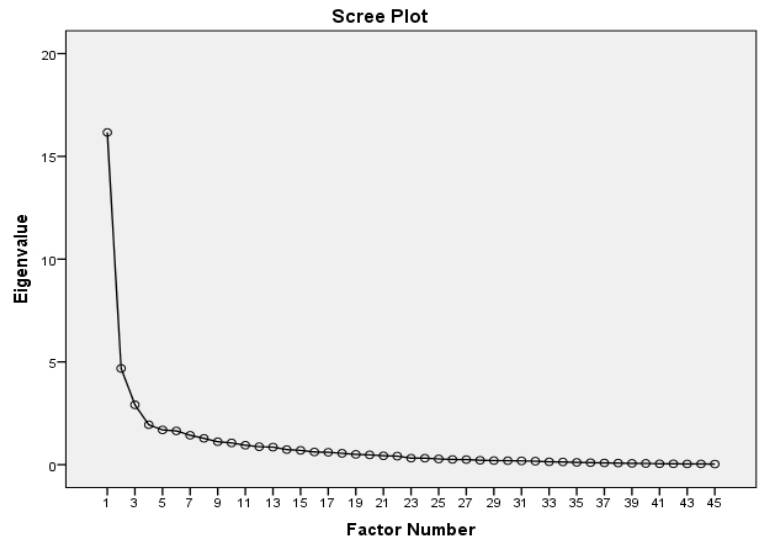

Figure 1. The curve extracted from the factor analysis of questionnaire.

Given the questions included separately by these 5 factors, the first factor was named brand association features, the second one was name brand association benefits, the third one was named fan based brand attitudes, the fourth one was named fan based brand identity, and the fifth one was named brand loyalty. The first and fourth factors included 12 items each, while the second, third, and fifth factors included 7, 6, and 8 items, respectively. The sum of five factors was 45 items. To calculate the final reliability, Cronbach's Alpha coefficient was calculated for each factor. The minimal Cronbach's Alpha coefficient was equal to 0.87 , while the maximal one was equal to 0.93 , and the Cronbach's Alpha coefficient mean was equal to 0.90 for each five factors.

Confirmatory factor analysis. The results of confirmatory factor analysis for items related to each factor obtained from exploratory factor analysis are presented in table 4. Given the fact that KMO index is greater than 0.5 in each of five items, and the significance level of Bartlett's test is less than 0.05 , it can be inferred that data obtained for factor analysis are appropriate for each of five items, and sampling is qualified. Also, the results in table 4 indicate that the factor weight related to five items introduced in exploratory analysis is greater than 0.5 . This matter shows high construct validity.

Table 4. The results of confirmatory factor analysis for five factors presented in FBBE questionnaire

\begin{tabular}{|c|c|c|c|c|c|c|c|}
\hline & Items & $\begin{array}{l}\text { Factor } \\
\text { weight }\end{array}$ & КМO & $\begin{array}{c}\text { Bartlett's } \\
\text { test }\end{array}$ & $\begin{array}{l}\text { Explained } \\
\text { variance }\end{array}$ & df & $\mathbf{X}^{2}$ \\
\hline \multirow{12}{*}{ 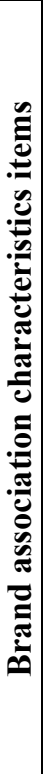 } & I like the star players of my favorite team. & 0.808 & \multirow{12}{*}{0.769} & \multirow{12}{*}{$\mathrm{p}=0.001$} & \multirow{12}{*}{58.49} & \multirow{12}{*}{66} & \multirow{12}{*}{13924.9} \\
\hline & $\begin{array}{l}\text { The head coach of my favorite team shows an } \\
\text { acceptable performance. }\end{array}$ & 0.800 & & & & & \\
\hline & $\begin{array}{l}\text { The executive officials of my favorite team are } \\
\text { efficient in its performance. }\end{array}$ & 0.760 & & & & & \\
\hline & $\begin{array}{l}\text { The head coach of my favorite team is a famous } \\
\text { individual in football. }\end{array}$ & 0.752 & & & & & \\
\hline & $\begin{array}{l}\text { The training sessions of my favorite team are held in a } \\
\text { stadium which increases encouragement of attendance. }\end{array}$ & 0.748 & & & & & \\
\hline & My favorite team's matches are exciting and nice. & 0.748 & & & & & \\
\hline & $\begin{array}{l}\text { It is very important that my favorite team } \\
\text { achieve championship. }\end{array}$ & 0.695 & & & & & \\
\hline & I like the design and color of my favorite team's costume. & 0.682 & & & & & \\
\hline & $\begin{array}{l}\text { I don't pay attention to whether my favorite } \\
\text { team wins or loses. }\end{array}$ & 0.657 & & & & & \\
\hline & $\begin{array}{l}\text { The manager of my favorite team is an efficient } \\
\text { person in football, and I like him. }\end{array}$ & 0.646 & & & & & \\
\hline & $\begin{array}{l}\text { I like watching star players' performances of } \\
\text { my favorite team. }\end{array}$ & 0.599 & & & & & \\
\hline & $\begin{array}{l}\text { My favorite team has a shining and successful } \\
\text { record of championship. }\end{array}$ & 0.511 & & & & & \\
\hline
\end{tabular}


Continue Table 4

\begin{tabular}{|c|c|c|c|c|c|c|c|}
\hline & Items & $\begin{array}{l}\text { Factor } \\
\text { weight }\end{array}$ & КМO & $\begin{array}{l}\text { Bartlett's } \\
\text { test }\end{array}$ & $\begin{array}{l}\text { Explained } \\
\text { variance }\end{array}$ & df & $X^{2}$ \\
\hline$\approx$ & $\begin{array}{l}\text { My favorite team helps improve society image } \\
\text { and brings credibility to my city. }\end{array}$ & 0.885 & \multirow{7}{*}{0.796} & \multirow{7}{*}{$\mathrm{p}=0.001$} & \multirow{7}{*}{61.05} & \multirow{7}{*}{66} & \multirow{7}{*}{14924.3} \\
\hline 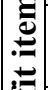 & $\begin{array}{l}\text { Thinking about my favorite team reminds me of } \\
\text { good memories of my fandom. }\end{array}$ & 0.885 & & & & & \\
\hline 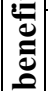 & $\begin{array}{l}\text { It is important that my family and friends } \\
\text { consider me to be a team fan. }\end{array}$ & 0.831 & & & & & \\
\hline \multirow{4}{*}{ 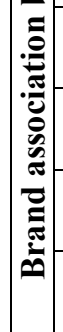 } & $\begin{array}{l}\text { I prefer to be my favorite team fan for my } \\
\text { friends' sake. }\end{array}$ & 0.783 & & & & & \\
\hline & $\begin{array}{l}\text { I feel proud when someone compliments on my } \\
\text { favorite team. }\end{array}$ & 0.746 & & & & & \\
\hline & $\begin{array}{l}\text { I remember different memories of my favorite } \\
\text { team fandom with my family and friends. }\end{array}$ & 0.656 & & & & & \\
\hline & $\begin{array}{l}\text { Speaking about my favorite team is a temporary } \\
\text { chance to escape from life's problems. }\end{array}$ & 0.647 & & & & & \\
\hline \multirow{6}{*}{ 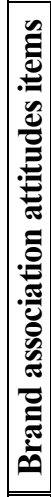 } & $\begin{array}{l}\text { Compared to my feelings toward other } \\
\text { professional teams, my favorite team means a } \\
\text { lot to me. }\end{array}$ & 0.884 & \multirow{6}{*}{0.856} & \multirow{6}{*}{$\mathrm{p}=0.001$} & \multirow{6}{*}{64.89} & \multirow{6}{*}{15} & \multirow{6}{*}{2986.97} \\
\hline & $\begin{array}{l}\text { I support my favorite team in public even if it } \\
\text { causes me problems. }\end{array}$ & 0.848 & & & & & \\
\hline & Supporting my favorite team is important to me. & 0.842 & & & & & \\
\hline & $\begin{array}{l}\text { I support my favorite team, because my friends } \\
\text { support the same team. }\end{array}$ & 0.791 & & & & & \\
\hline & I have thorough information on my favorite team. & 0.735 & & & & & \\
\hline & $\begin{array}{l}\text { When I speak of my favorite team, I usually } \\
\text { say, "we are better than them," in comparison } \\
\text { with other teams. }\end{array}$ & 0.721 & & & & & \\
\hline \multirow{12}{*}{ 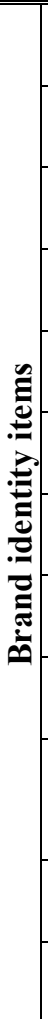 } & $\begin{array}{l}\text { My favorite team's logo creates compulsory } \\
\text { motivation for "Self-improvement" in me. }\end{array}$ & 0.884 & \multirow{12}{*}{0.892} & \multirow{12}{*}{$\mathrm{p}=0.001$} & \multirow{12}{*}{56.17} & \multirow{12}{*}{66} & \multirow{12}{*}{8939.24} \\
\hline & $\begin{array}{l}\text { My favorite team's logo is a reflection of my } \\
\text { team's goal and my goal of fandom. }\end{array}$ & 0.878 & & & & & \\
\hline & $\begin{array}{l}\text { My favorite team's logo is exciting, valuable, } \\
\text { and complicated. }\end{array}$ & 0.868 & & & & & \\
\hline & $\begin{array}{l}\text { My favorite team's logo has a strong and } \\
\text { worthy character. }\end{array}$ & 0.859 & & & & & \\
\hline & $\begin{array}{l}\text { I have an internal relationship with my favorite } \\
\text { team's logo. }\end{array}$ & 0.840 & & & & & \\
\hline & $\begin{array}{l}\text { My favorite team's logo retells me some traits } \\
\text { of my own. }\end{array}$ & 0.818 & & & & & \\
\hline & $\begin{array}{l}\text { My favorite team makes different people } \\
\text { become friends. }\end{array}$ & 0.739 & & & & & \\
\hline & $\begin{array}{l}\text { My favorite team is famous among football } \\
\text { teams. }\end{array}$ & 0.665 & & & & & \\
\hline & $\begin{array}{l}\text { My favorite team causes a good relationship } \\
\text { between fans. }\end{array}$ & 0.622 & & & & & \\
\hline & $\begin{array}{l}\text { When the name of my favorite team is spoken } \\
\text { somewhere, its logo comes to my mind } \\
\text { automatically. }\end{array}$ & 0.597 & & & & & \\
\hline & $\begin{array}{l}\text { My favorite team associates with decent internal } \\
\text { values. }\end{array}$ & 0.581 & & & & & \\
\hline & $\begin{array}{l}\text { My favorite team bears a rich culture and } \\
\text { history. }\end{array}$ & 0.502 & & & & & \\
\hline
\end{tabular}

Khodadadi, M. R., et al. (2014). Ann Appl Sport Sci, 2(2): 83-100. 
Continue Table 4

\begin{tabular}{|c|c|c|c|c|c|c|c|}
\hline & Items & $\begin{array}{l}\text { Factor } \\
\text { weight }\end{array}$ & КМО & $\begin{array}{c}\text { Bartlett's } \\
\text { test }\end{array}$ & $\begin{array}{l}\text { Explained } \\
\text { variance }\end{array}$ & df & $X^{2}$ \\
\hline \multirow{8}{*}{ 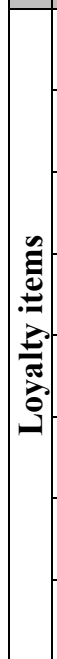 } & $\begin{array}{l}\text { I try to make my family and friends become my } \\
\text { favorite team's fan. }\end{array}$ & 0.852 & \multirow{8}{*}{0.819} & \multirow{8}{*}{$\mathrm{p}=0.001$} & \multirow{8}{*}{58.29} & \multirow{8}{*}{28} & \multirow{8}{*}{7094.61} \\
\hline & $\begin{array}{l}\text { I can never change the bond between me and } \\
\text { my team to another team. }\end{array}$ & 0.845 & & & & & \\
\hline & $\begin{array}{l}\text { I consider myself to be a committed fan for my } \\
\text { favorite team. }\end{array}$ & 0.844 & & & & & \\
\hline & $\begin{array}{l}\text { Joining more fans to my favorite team makes } \\
\text { me happy. }\end{array}$ & 0.823 & & & & & \\
\hline & $\begin{array}{l}\text { I watch my favorite team's matches regardless } \\
\text { of who the opponent is. }\end{array}$ & 0.821 & & & & & \\
\hline & $\begin{array}{l}\text { I will forgive my favorite team when it fails on } \\
\text { the way of success. }\end{array}$ & 0.676 & & & & & \\
\hline & $\begin{array}{l}\text { I at particular times purchase some of the goods } \\
\text { produced by my favorite team. }\end{array}$ & 0.620 & & & & & \\
\hline & $\begin{array}{l}\text { I surely participate in my favorite team's } \\
\text { matches regularly and at certain times. }\end{array}$ & 0.564 & & & & & \\
\hline
\end{tabular}

\section{DISCUSSION and CONCLUSION}

In the present research, brand equity has been assessed according to brand association method and based on four main dimensions of characteristics, benefits, attitudes, and identity. Four dimensions of brand equity are evaluated through 37 items of Iranian supreme football league fans which are resulted by omitting 5 items in confirmatory analysis. The investigating tools are consistent with this idea that fans loyal to brand are the providers of constant revenue of income, regardless of team's performance, and 15 dimensions with 45 items have been presented to study the behavioral and attitude loyalty in the final FBBE questionnaire. Also in confirmatory factor analysis, the factor weight of all items related to five factors introduced in exploratory analysis is greater than 0.5 which shows high construct validity. The results of current research are consistent with the results taken from researches done by Gladden and Funk (2002), Lin (2007), Bauer, Stokburger-Sauer, and Exler (2008), Ross, Russell, and Bang (2007), Javani et al. (2012), and Biscaia et al. (2013) (7, 8, 13,
$20,24)$, and it considers the effects of brand association on sports customers' loyalty to be important and effective. Javani et al. (2012) studied football brand equity in three major dimensions and 49 items in club fans of Sepahan and Zob Ahan (8). Gladden and Funk (2002) studied brand management in professional sport through investigating the relationship between brand associations (anything which is related to a particular brand in customers' minds.) and brand loyalty in a comprehensive research and by studying fans and professional sports customers (10). Keller's conceptual model in brand equity was used in this study so that the dimensions of brand association in sports get determined (29). 13 dimensions have been identified as potential dimensions of brand association in sport. In a study titled "Experimental evaluation of spectator- based brand equity" by Ross, Russell, and Bang (2007), 49 items and 12 constructs of an appropriate and logical model was suggested by one sample of professional basketball spectators in studying the development of understanding of stuck owners' rights under the sports logo in the eye of customers by 
presenting experimental support for the model (13). The above-mentioned study is an initial and experimental test for Spectator-Based Brand Equity (SBBE) model as well as showing the importance of discovering methods to understand spectator-based share right which is statistically confirmed in it. In a study titled "SBBE in professional football" by Biscaia et al. (2013), the results acquired by confirmatory factor analysis indicated that an acceptable fitting of data with the model and internal relationship has confirmed an initial construct and specified its dimensions in ten ones (24). These ten dimensions include 1) trademark brand, 2) score, 3) social interaction, 4) commitment, 5) team's history, 6) organizational characteristics, 7) team's success, 8) head coach, 9) management and staff, and 10) stadium. The considerable point in the research by Biscaia et al. (2013) is focusing on the spectators, and it indicates that the researcher did not consider loyalty, which is the major characteristic of a fan rather than a spectator, and considered SBBE only in a limited frame of two dimensions i.e. characteristics and benefits of brand associations forming only two dimensions out of five main ones (24). However, it is believed that $80 \%$ of a company's or organization's interest comes from $20 \%$ of customers loyal to that company or organization.

In this research, the characteristics dimension is evaluated through subscales of star player, head coach, stadium, championship record, products, and management. The characteristics of a sports brand, in the research by Gladden and Funk (2002), Ross, Russell, and Bang (2007), and Biscaia et al. (2013), include subscales of trademark logo and the club's history as well as what was mentioned earlier, and these two subscales were presented in confirmed tools of the present research in brand association identity brand $(10,13,24)$. The subscale of club's private stadium which is studied in sports brand equity in conducted researches bears lower correlation in other items, because sports stadium is not considered as one of the assets of a sports club in Iranian supreme league of football so that it leads to omitting the item with negative correlation coefficient. This result is not consistent with the researches by Sajadi, Khabiri, and Alizadeh (2013), Biscaia et al. (2013), Javani et al. (2012), Bauer, Stokburger-Sauer, and Exler (2008), Lin (2007), Ross, Russell, and Bang (2007), and Gladden and Funk (2002) (7, 8, 10, 13, $18,20,24)$. In all these researches, the necessity of a private, modern, and appropriate stadium is emphasized to acquire football brand equity. On the other hand, Moshabbeki et al. (2014) considered star players, logo, fans, record, stadium's performance, and non-player personnel to be parts of football brand identity dimensions by using success factor analysis (19). Another important point in the research by Gladden and Funk (2002) is the importance of providing a desirable experience and special access to players, caches, and other team administrators as a tool to create a high sense of conjunction with team in fans to be a part of team (10). Of course, this result is consistent with the research by Sajadi, Khabiri, and Alizadeh (2013) based on the inefficiency of subscale of sports stadium (18).

The dimension of brand association benefit is examined by FBBE questionnaire through subscales of fan identity, escape from daily routine, being proud of nation, patriotism, and fitting in peer groups. In the introduced tool, this dimension is evaluated by 9 items of Iranian supreme football league fans. The subscales of this dimension are consistent with the research by Gladden and Funk (2002) and Javani et al. (2012) including 15 items $(8,10)$. In the research by Gladden and Funk (2002), sports teams' ability in providing patriotic memories was a good predictor of brand loyalty and 
emphasizing on the need for understanding the organizing role of patriotic memories among fans. The need for escape from daily routine and fatigue had a positively significant relationship with brand loyalty, and according to these findings, it has been highly emphasized on increasing the frequency of fans' attendance and also holding parties which teams usually hold to meet fans' need to escape from daily routine (10).

Finally, coordinated efforts in order to increase entertainment experiences supported by the football club indicated that presenting a sports product (both the game and environmental elements) can positively be related to brand loyalty, and using the marketing strategies were known as a successful traditions including employing a star player or fitting into a group of peers through fan recruitment methods. This result is inconsistent with findings by Sajadi, Khabiri, and Alizadeh (2013) in which the scale for acceptance by peers group had a negative effect on loyalty (18), because this subscale has been holding a high factor weight in the present research.

The dimension of brand association attitude is evaluated by FBBE questionnaire through subscales of knowledge and information, importance, and interactions. This dimension is examined through 7 items of Iranian supreme football league in the designed questionnaire. The subscales of this dimension are consistent with the research by Gladden and Funk (2002), Javani et al. (2012), and Sajadi, Khabiri, and Alizadeh (2013) (8, 10, 18). Having knowledge and information about fans' favorite club leads to decisions which are in club's interests in the present research, too, and when club importance for an fan is accompanied by his/her interactions in life, fan loyalty will be portrayed better for the football club. Therefore, the direct relationship of club authorities, players, other assets with fans can create an attitude which will help acquire intangible assets of club and create a very wonderful added value.

In the present research, brand equity is made through FBBE questionnaire based on Kapferer's model (2008) (25) and Koo's questionnaire (2009) (22), and it is evaluated through subscales of body, personality, culture, relationship, reflection, and selfimage. This dimension is evaluated through 12 items of Iranian supreme football league fans in this questionnaire. In the research titled "Designing a pattern for brand equity of Iranian sports industry (case study: football supreme league)" by Moshabbeki et al. (2014), it is stated that football is an industry in which branding and its backbone i.e. brand equity bears high importance, in a way that researchers presented certain brand patterns for football in countries well-known in football industry (19). The researchers presented the pattern for brand identity factors of present teams in Iranian supreme football league in this research, considering modern viewpoints of brand identity theory (22) and opinions by journalists and fans. Finally, 10 dimensions were presented for brand identity of country's football. However, all of these 10 dimensions are the same brand association dimensions which were comprehensively stated by Gladden and Funk (2002) (10). Therefore, the results of present research are not consistent with Moshabbeki et al. (2014), and Kapferer's comprehensive brand identity model which studies identity in two tangible and intangible dimensions and is one of the most documented brand identity models has been neglected $(19,25)$. Brand identity comes from the quality and characteristics of the brand itself, and its subscales should not be forgotten in football brand. Since when signs and logos are gathered together, they brag on their power, prestige, color, and style toward other logos, and neglecting this fact hurts the club with loss which is not probably seen only in financial balance sheet and leads to fans' disloyalty. The tangible identity in this 
scale is evaluated through subscales of body, relationship, and reflection, while intangible identity is evaluated through subscales of personality, culture, and self-image. The result of effective brand identity factor weight from FBBE questionnaire is consistent with the research by Dehdashti, Jafarzadeh Kenari, and Bakhshizadeh (2012), Boroumand et al. (2011), and Gwinner and Bennett $(2008)(9,17,30)$.

In the present research, brand loyalty is evaluated through the validity of FBBE questionnaire which was designed according to model of Møller Jensen and Hansen (2006) (26). Attitudinal loyalty includes subscales of stating preferences, commitment, or customer's intention to purchase, and behavioral loyalty is evaluated through subscales of repeated use of services and repurchase. In his study, Javani et al. (2012) considered loyalty as a whole (8), while no separate subscale has been presented to assess attitudinal and behavioral loyalty to football brand in the research by Gladden and Funk (2002) (10). Attitudinal and behavioral loyalty to sports brand have not been studied and it is essential that managers seek football fans opinions by following the results of present research and provide services compatible to their needs in order to become successful in competing to attract fans and supporters. There are three applicable concepts in customer's loyalty to the brand. First, brands should create a name, logo, brand equity, and brand image when managers' profit-seeking loyalty increases. Second, a decent image of brand should be created and propagated in order to increase customers' willing loyalty. Third, customers distinguish themselves from rivals in order to keep the previous state of loyalty. Efficient management of dimensions related to a sports brand let managers the likelihood to develop brand's power. For example, if it is specified that describing team's characteristics is an important and strong matter, managers can use it to choose, employ, and sign contract with players with desirable description by fans and managers. For instance, Oakland Raiders were often known as bad boys in the national football league. When this organization employed Randy Moss, everybody imagined that he would recall the same image and enhance team's image of cruelty, probably. Sports managers should have a psychological commitment toward their sports brand. The results indicate that introducing and nationalizing has enough effect on the awareness of brand. With a high level of commitment, a very high extent of awareness is acquired for the brand, and as a result of this awareness, sports consumers can know marketing communities related to sports brand very better. This gives the managers a competitive privilege in the criteria of efficiency and marketing sources, leading to more success in reaching target markets. For example, if consumers are able to have a better understanding of marketing communities presented by an institute, that institute can make sure that sources used in marketing communities are not taken as jokes. Moreover, it protects the brand against rivals in achieving enough products. The previous studies indicate that the initial associations which are recalled by memory decrease the potential of remembering more associations. The likelihood to remember a specific relationship by brain is decreased, but the number of relationships already remembered increases. Giving limited sources of foreign information to customers decreases their interest to compare brands and reduces their tendency to purchase products and services from the institute. As the last word, awareness will have an efficient role in choosing the brand and provides more benefits for the institute through selling tickets in return. 


\section{REFFRENCES}

1. Bodet $\mathrm{G}$, Chanavat N. Building global football brand equity: lessons from the Chinese market. Asia Pacific Journal of Marketing and Logistics. 2010;22(1):55-66.

2. Jalalzadeh SR, Ekhtiari M, editors. Brand value in the banking industry. First International Conference of Banking Services Marketing (BSM); 2009; Tehran, Iran. [Article in Farsi].

3. Bridgewater S. Football Brands: Palgrave Macmillan; 2010. 194 p.

4. Broadbent S, Bridson K, Ferkins L, Rentschler R, editors. Brand love, brand image and loyalty in Australian elite sport. Doing more with less: Australian and New Zealand Marketing Academy Conference (ANZMAC ); 2010; Christchurch, New Zealand: ANZMAC.

5. Elahi A, Sajjadi N, Khabiri M, Abrishami H. Barriers to the Development of Revenues from Sponsorship in Iran Football Industry. Journal of Sport Management. 2009;1(1):189-202 [Article in Farsi].

6. Ross SD, Bang HJ, Lee SB. Assessing brand associations for intercollegiate ice hockey. Sport Marketing Quarterly. 2007;16(2):106-14.

7. Bauer HH, Stokburger-Sauer NE, Exler S. Brand image and fan loyalty in professional team sport: A refined model and empirical assessment. Journal of sport Management. 2008;22(2):205-26.

8. Javani V, Soltan Hossein M, Rahnama N, NasrEsfahani D. Study of effective factors of fans brand loyalty in Iranian professional football league. Journal of Physical Education and Sport Management. 2012;3(1):8-13.

9. Boroumand M, Shahbazi M, Kosarneshan MR, Javaheri M, Kamel, editors. Examine the backgrounds and consequences of brand identity (Case Study: Brand Hacoupian). Forth International Marketing Management Conference (MM); 2011; Tehran, Iran. [Article in Farsi].

10. Gladden JM, Funk DC. Developing an understanding of brand associations in team sport: Empirical evidence from consumers of professional sport. Journal of sport Management. 2002;16(1):54-81.

11. Devasagayam PR, Buff CL, Aurand TW, Judson KM. Building brand community membership within organizations: a viable internal branding alternative? Journal of Product \& Brand Management. 2010;19(3):2107.

12. Akhavan S, Fomani. The role of brand personality on consumer behavior and branding challenges in Asia. Rasht, Iran: Rasht Branch, Islamic Azad University; 2011 [Thesis in Farsi].

13. Ross SD, Russell KC, Bang H, editors. An Empirical Assessment of Spectator-Based Brand Equity. 2007 North American Society for Sport Management Conference (NASSM 2007); 2007; Ft. Lauderdale, Florida.

14. Keshkar S, Ghasemi H, Tojjari F. Sports Marketing Management. 1st ed. Tehran: Elm-o-Harakat (Science and Movement); 2011 [Book in Farsi].

15. Ross SD. A conceptual framework for understanding spectator-based brand equity. Journal of sport Management. 2006;20(1):22-38.

16. Berry L. Cultivating service brand equity. J of the Acad Mark Sci. 2000;28(1):128-37.

17. Dehdashti Z, Jafarzadeh Kenari M, Bakhshizadeh A. Investigating Brand Social Identity Perspective and Its Influence on Brand Loyalty Development the Case of Kaleh Dairy Company. New Marketing Research Journal. 2012;2(2):87-105 [Article in Farsi].

18. Sajadi SN, Khabiri M, Alizadeh A. The factors influencing fan's loyalty toward the most popular teams brand in Iran's professional football league. Sport Management Review. 2013;5(18):81-100 [Article in Farsi].

19. Moshabbeki A, Esfahani, Vahdati H, Khodadad Hosseini SH, Ehsani M. Designing The Brand Identity Model of Iranian Sports Industry (Case Study: Football Premier League). Management Research in Iran. 2014;17(4):20323 [Article in Farsi].

20. Lin YT. Factors influencing baseball fan's brand loyalty: a comparison of Florida Marlins and Tampa Bay Devil Rays: Lynn University; 2007.

21. Carlson BD, Donavan DT. Human Brands in Sport: Athlete Brand Personality and Identification. Journal of Sport Management. 2013;27(3):193-206.

22. Koo JJ. Brand management strategy for Korean professional football teams: A model for understanding the relationships between team brand identity, fans' identification with football teams, and team brand loyalty: Brunel University; 2009.

23. Cui W. Creating Consumer-based brand equity in the Chinese sports shoes market: Measurement, challenges and opportunities: Aalborg University; 2011.

24. Biscaia R, Correia A, Ross S, Rosado AF, Maroco J. Spectator-Based Brand Equity in Professional Soccer. Sport Marketing Quarterly. 2013;22:20-32.

25. Kapferer JN. The New Strategic Brand Management: Creating and Sustaining Brand Equity Long Term. 4th ed: Kogan Page; 2008. 560 p. 
26. Møller Jensen J, Hansen T. An empirical examination of brand loyalty. Journal of Product \& Brand Management. 2006;15(7):442-9.

27. Lawshe CH. A QUANTITATIVE APPROACH TO CONTENT VALIDITY1. Personnel Psychology. 1975;28(4):563-75.

28. Streiner DL, Norman GR. Health Measurement Scales: A practical guide to their development and use. 4th ed: OUP Oxford; 2008. $352 \mathrm{p}$.

29. Keller KL. Conceptualizing, measuring, and managing customer-based brand equity. The Journal of Marketing. 1993;57(1):1-22.

30. Gwinner K, Bennett G. The Impact of Brand Cohesiveness and Sport Identification on Brand Fit in a Sponsorship Context. 2008;22(4):410 - 26. 
تازههاى علوم كاربردى ورزش

مقاله اصيل

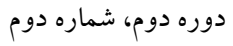

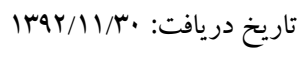

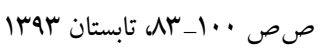

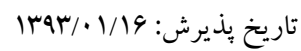

\section{تحليل عاملى بر سشنامه ارزش ويزه برند مشتى بر هوادار فوتبال در باشَاهاهاى ليَ برتر ايران 'محمد رسول خدادادى *، 'ابوالفضل فر اهانى، ‘حميد قاسمى، ‘حبيب هنرى}

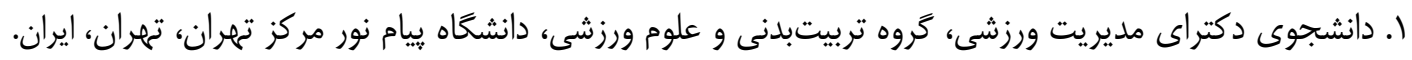

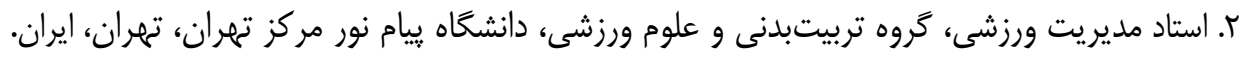

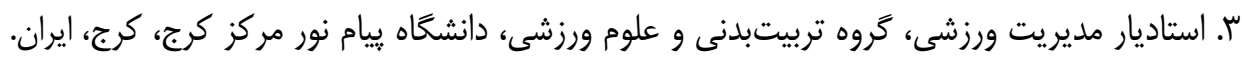

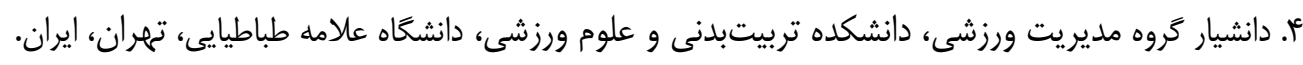

جكيده

هدف اين يزوهش اعتباريابى و تحليل عاملى يرسشنامه ارزش ويزه برند مبتنى بر هوادار فوتبال در باشكاههاى ليحى برتر ايران بود. يُوهش

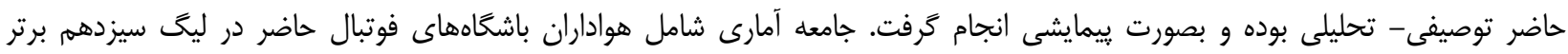

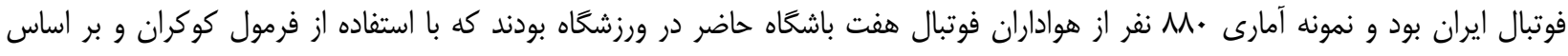

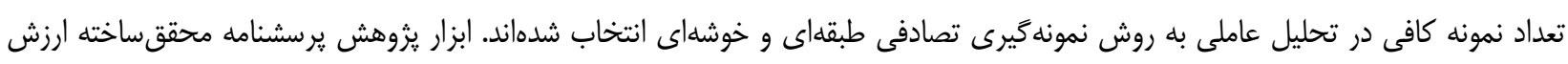

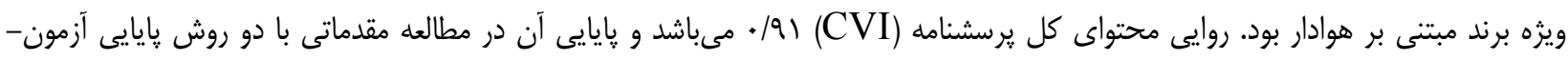

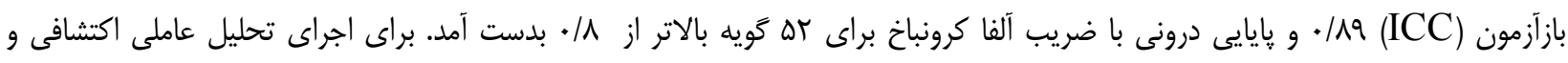

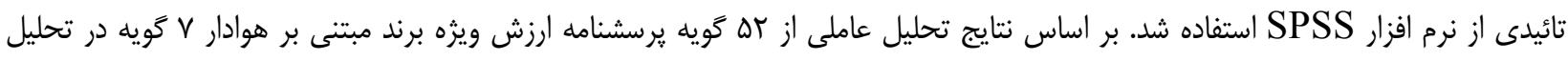

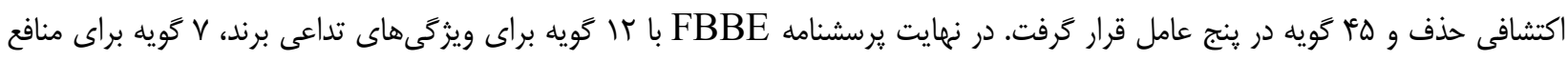

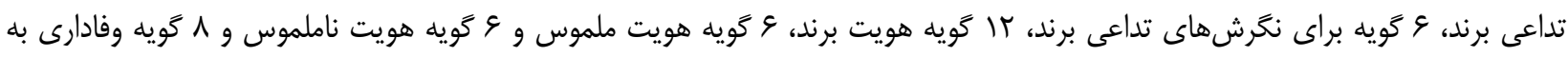

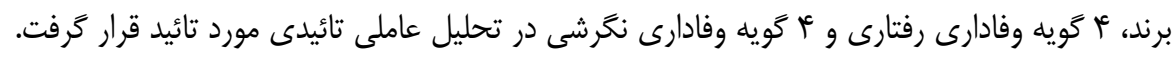
وازَّان كليدى: تداعيات برند، هويت برند، وفادارى برند، هواداران، فوتبال. 
